\title{
「自動車分野におけるレーザー利用の新展開」特集号によせて
}

\author{
阿部信行 \\ 大阪大学 接合科学研究所スマートプロセス研究センター（†567-0047 茨木市美穂ヶ丘11-1）
}

\section{Preface to Special Issue on Advances in Laser Use for Automotive Field}

\author{
Nobuyuki ABE \\ Smart Processing Research Center, Joining and Welding Research Institute, Osaka University, 11-1 Mihogaoka, Ibaraki, Osaka 567-0047
}

(Received April 27, 2010)

地球温暖化や資源枯渇による，世界規模の省エネル ギー・省資源・ $\mathrm{CO}_{2}$ 排出削減の流れを受け, 自動車産業 は大きな曲がり角に来ており, 電気自動車への移行が急 務となっている．動力がガソリンエンジンから電気モー ターに変わるということは, 駆動系の効率化とともに車 体のさらなる軽量化が必要であることを意味する。モー ターや電池の容量を低減するために, それらを含めた車 体全体重量を今までより以上軽くするための加工技術が 必要とされている。

車体材料の薄板軽量化を促進するためには, より比強 度の高い材料へと移行する必要があり, 現在の鋼材から ハイテンへ, さらにアルミニウム合金からチタン合金, マグネシウム合金へと進んでいくであろう。アルミニウ ム合金からチタン合金, マグネシウム合金へと適用が進 むにつれ，材料価格は高価になり，必要な部分にのみ必 要な特性を持った材料を必要最小限使用することが求め られ，異材接合技術に対する要求が大きくなるものと考 えられる。

金属材料ばかりではなく比強度の高い新素材特にFRP 系の複合材料を利用する動きも考えられている. 現在航 空機に使用されているCFRP (炭素繊維強化プラスチッ ク)などはその究極材料であろう。これらは価格の高さ 以上に切断技術や接合技術が追い付いていないのが現状 であるが，レーザー加工機そのものの改良・開発の進展 とともに，新たな溶接施工プロセスを開発する必要があ る.

必要な部分に必要なエネルギーのみを注入できるレー
ザー加工は，熱加工ツールとして省エネルギー・省資源 技術であるとともに，これらの異材あるいは新素材の接 合についても大きな役割を果たすことになるであろう.

また車載電気・電子部品に目を移すと, これらもさら に小型化軽量化が求められており，部品が小さくなれば なるほどその特性を発揮するレーザー加工は，その意味 で高実装密度電子部品の接合技術には最適のツールとな る。現在使用されているはんだ付に変わるレーザー直接 接合やレーザー配線技術を，近年著しく性能が向上した ガルバノミラー技術と効果的に融合させることにより, 高速化・高精度化が進められている。このためにより小 型で高品質のパルスファイバレーザーの開発も必要とさ れる。 またガルバノミラーシステムの性能向上やコント ロール技術の向上とともに，信頼性の高い微小入熱高速 接合技術の開発が必要となる。

さらに接合ばかりではなく, ガルバノミラーシステム による表面処理技術も部品が小さくなればレーザーの加 工対象としても十分視野に入るようになり，表面処理に よる摩擦低減技術は, 回転部品の多い自動車にとっては 必要不可欠のものになるであろう.

本特集ではこれらの中からレーザーを利用した運転性 能の向上から，エンジンシステムの効率化，LEDによる 高効率照明をはじめ, 将来の電気自動車製造に欠かせな い異種材料接合技術や炭素繊維の利用について解説をし ていただく、自動車分野におけるレーザー利用の現状と 今後の展開を知る一助になれば幸いである。 